\title{
Resimli Bağdat hanedan silsilenâmelerinin karakteristik özellikleri
}

Abdurrahim AYĞAN ${ }^{1}$

Araştırma Makalesi

Gönderi Tarihi:30.10.2020

\section{Özet}

Silsilenâmeler, Osmanlı minyatür sanatında tarih konulu eserler grubuna giren bir türdür. Bu eserlerde Âdem'den başlanarak, peygamberler, krallar ve sultanlar, aralarındaki soy ilişkisi gözetilerek daireler içerisinde temsil edilir. En sonda ise Osmanlı hanedanı bir dizi halinde sıralanır. Osman Gazi'den başlayan bu dizi, el yazmasının hazırlandığı dönemde saltanatı süren sultana kadar devam eder. Silsilenâmeler iki ana bölümden oluşmaktadır. Birinci bölümde dünya tarihinin kısa bir özeti sunulur, ikinci bölümde ise ilk insan Âdem'den başlayan ve Osmanlı hanedanının son üyesiyle son bulan bir şematik dizi yer alır. Resimsiz silsilenâmelerde dairelerin içerisine hükümdarların adları yazılır, resimli örneklerde ise madalyonlar içerisine portreleri çizilir. Silsilenâmeler iki farklı edebî geleneğin birleşimi olarak ele alınabilir. Öncelikle bu eserler, bir hanedanın soyunu ele alan bir şeceredir. Bunun yanı sıra, ilk insandan başlamak üzere çeşitli dönemleri, yazıldığı tarihe kadar anlatan bir dünya tarihi niteliği taşır.

Silsilenâmeleri sanat tarihi açısından resimli ve resimsiz olmak üzere iki gruba ayırmak mümkündür. Farklı dönemlere ait birçok resimsiz Silsilenâme nüshası mevcuttur. Tespit edilen resimli nüshalar ise 13-14 civarındadır. Osmanlılarda resimli ilk örnekler Osmanlının Bağdat eyaletinde 16. yüzyıl sonlarında ortaya çıkmıştır. Çalışmamızda Bağdat’ta hazırlanmış resimli örnekleri, Topkapı Saray Müzesi Kütüphanesi’nde kayıtlı dört nüsha (TSMK H. 1324, TSMK H. 1591, TSMK A. 3110, TSMK H. 1624) ile Dublin Chester Beatty Library’de (CBL. T. 423) bulunan bir nüsha çerçevesinde inceleyeceğiz.

Anahtar Kelimeler: Osmanlı Soyağacı, Osmanlı Minyatür Sanatı, Soy, Soyağacı, İslam Resim Sanatı.

\section{Characteristic features of illustrated Baghdad dynastic genealogies}

\begin{abstract}
Silsilenames are a type of historical manuscripts in Ottoman miniature art. In these works, starting from Adam, prophets, kings and sultans are represented in circles, considering the lineage relationship between them. At the end, the Ottoman dynasty is lined up in a series. This series, which starts with Osman Gazi, continues until the sultan, who continued his reign in the period when the manuscript was prepared. Silsilenâmes contain two main parts. In the first part, a brief summary of world history is presented, while in the second part, there is a schematic sequence starting from the first man, Adam, and ending with the last member of the Ottoman dynasty. The names of the rulers are written inside the circles in the unillustrated silsilenâmes. In the illustrated examples, portraits are drawn inside medallions. Silsilenâmes can be considered as a combination of two different literary traditions. First of all, these works are a genealogy that includes the ancestry of a dynasty. In addition, it has the characteristics of a world history which contains various periods starting from Adam until the date it was written.

It is possible categorise Silsilenames into two groups as illustrated and non-illustrated in terms of art history. There are many copies of unillustrated Silsilename belonging to different periods. The illustrated copies are around 13-14. The first illustrated examples in the Ottomans appeared in the Ottoman state of Baghdad in the late 16th century. In this study, we will examine illustrated examples prepared in Baghdad within the framework of four copies registered in the Topkapı Palace Museum Library (TSMK H. 1324, TSMK H. 1591, TSMK A. 3110, TSMK H. 1624) and one copy in the Chester Beatty Library, Dublin (CBL. T. 423).
\end{abstract}

Key Words: Ottoman Genealogy, Ottoman miniature art, Lineage, Genealogic tree, Islamic painting.

\footnotetext{
${ }^{1}$ Doktor Öğretim Üyesi, Şırnak Üniversitesi, Güzel Sanatlar Fakültesi, Resim Bölümü, aaygan@hotmail.com.
} 


\section{Giriş}

Sözlükte zincir, sıra gibi anlamlara gelen Silsilenâme bir soyun, bir neslin veya bir tarikatın geçmişle olan bağını gösteren vesikalar anlamına gelmektedir (Pakalın, 1983, s. 226-227; Tosun, 2009, s. 206). Osmanlı kitap sanatlarında ise, kökü ensâb, şecere gibi ilim kollarına dayanan, ilk insan Hz. Âdem'den başlayarak Osmanlı sultanlarına kadar tarihte yaşamış peygamberleri, sultan ve şahları kendi içerisinde soy ilişkisine göre şematik biçimde sınıflandıran dünya tarihi niteliğinde bir eser türünü ifade eder. Silsilenâmeleri 10. yüzyıldan itibaren İslam dünyasında yaygınlaşan genel dünya tarihlerinden ayıran en önemli özelliği içerisinde soy ilişkisini gösteren şema, şekil ve madalyonları ihtiva etmesidir. Sultan silsilelerinin yanı sıra özellikle 14. yüzyıldan itibaren yaygınlık gösteren ve tarikatlardaki hilafet sırasını gösteren eserlere de Silsilenâme adı verilmiştir. Silsilenâme-i Celvetî, Silsilenâme-i Bektaşi'ye bunlara örnek olarak gösterilebilir.

Silsilenâmeler Osmanlı kitap sanatları içerisinde önemli bir grup oluşturur. Ali Emiri’nin (ö. 1924) Yanya' da müfettişlik yaptığı sırada eline geçtiği "Cam-1 Cem Âyin" adlı Silsilenâme bu türün ilk örneklerinden biri olarak gösterilebilir. Eser, Hasan b. Mahmut Beyâtî̀ye ait olup, hicri 886/1481-82 tarihlidir ve Ali Emirî tarafından hicri 1331/1912-1314 yılında İstanbul' da neşredilmiştir (Ayğan, 2017, s. 111). Nesir olarak hazırlanan bu eserle aynı dönemlerde hazırlandığ 1 varsayılan başka bir silsilename (TSMK H. 1590) ise II. Bayezid (1481-1512) için hazırlanmıştır (Bağcı, 2000, s. 194). Bu eser şematik düzende hazırlanmıştır. İlk örneklerden sonra bu tür sürekli gelişim göstermiş, 16. yüzyıl sonu ve 17. yüzyıl başlarında sayfa tasarımında değişikliğe gidilmiştir. Böylece madalyon portreler ihtiva eden yazma eserler ortaya çıkmıştır. Madalyon içerisinde sultanların betimlenmesi geleneği sonraki yüzyıllarda portrecilik içerisinde varlığını sürdürmüştür. Çalışmamızda Osmanlı Sultanları için hazırlanan resimli silsilenâme eserlerinden Bağdat’ta hazırlanan beş nüshayı ana hatlarıyla tanıtmaya çalışacă̆ız.

\section{Bağdat silsilenâmeleri}

Tarihi ve kültürel birikimiyle Osmanlı devletinin en önemli eyaletlerinden olan Bağdat, saray dışında gelişen kitap sanatlarının da önde gelen üretim merkezlerinden biriydi (Milstein, 1990, s. 36; Çağman, 1979, s. 651; Bağc1 vd., 2006, s. 246; Taner, 2016, s. 523). Resimli Silsilenâme örnekleri de ilk olarak Bağdat'taki atölyelerde hazırlanmıştır.

Tasavvufun beşiği olan Bağdat'ın kültürel zenginliğine farklı Sûfi akımların önemli katkıları olmuştur. Sanata yakın duran Mevlevilere ait dergâhlar, 16-17. yüzyıllarda kimi minyatürlü eserlerin hazırlanmasına da öncülük etmiştir (Çağman, 1979, s. 651).

Silsilename ketebelerinde yer alan hicri 1006 tarihi, Sokullu Mehmet Paşa'nın (ö. 1579) oğlu Hasan Paşa'nın (ö. 1602) 1598-1602 yılları arasında Bağdat'ta valilik yaptığı döneme denk gelmektedir. Hasan Paşa zengin bir koleksiyona sahip bir kitapsever olarak tanınmaktadır. Onun Bağdat'ta görev yaptığ1 dönemde el yazması eserlerin hazırlanmasında katkısının olduğu bilinmektedir. (1) Silsilenâmeler de bu el yazmaları arasında gösterilmektedir. Sokolluzâde Hasan Paşa gibi muktedir ve zengin bir devlet adamının hamiliğini yaptığı bu eserlerin Osmanlı saltanatının dünya hükümranlığına dayanan ideolojisini eyaletlere yaymada önemli bir işlev gördüğü düşünülebilir (Bağc1, 2000, s. 198).

16. yüzyıl sonlarında yeni bir anlayışa ortaya çıkan bu eser grubunun resimli ve resimsiz nüshaları günümüze ulaşmıştır. Resimli ve resimsiz eserler silsilelerin kurgusu ve tasarım biçimleri olarak standart bir görünüm arz eder. Resimli eserlerdeki minyatürler de üslup ve ikonografya açısından birkaç örnek dışında birbirinin tekrarıdır. (2) Bu çalışmada günümüze ulaşan beş nüsha üzerinde duruldu. Aralarındaki farklılıklara göre iki gruba ayırdı̆̆ımız bu örneklerin birinci grubunda Topkapı Saray müzesinde bulunan, H. 1591, H. 1324 ve Dublin CBL T.423 numaralı nüshalar, ikinci grubunda ise Topkapı Saray Müzesi Kütüphanesi'nde yer alan A. 3110 ve H. 1624 numaralı silsilenâmeler yer alır (Tablo 1).

Silsilenâmelerde kurgusal açıdan temel farklılıklardan biri birinci gruptakilerin Arapça bir Hz. Muhammed şeceresini ihtiva etmesidir. Silsilenâmelerde bir gelenek olarak ketebe kaydı bu şecerenin sonunda yer alır. Bu farklılık eserlerin tanımlanmasında temel ölçütlerdendir zira şecere içermeyen nüshalarda ketebe kaydı bu sebepten ötürü bulunmaz. 
Şecere ihtiva eden birinci gruptaki üç eser hicri 1006 tarihli olup; Topkapı Saray Müzesi Kütüphanesi'ndeki H. 1591 ve H. 1324 numaralı nüshaların hattatı Yusuf b. Muhammed Dizfûlî’dir. Dublin Chester Beatty T. 423 nüshasının hattatı ise Ebû Tâlip İsfehânî'dir. Her üç eserin ketebe kaydındaki "Sâkin-i Bağdat" ibaresi bu eser grubunun Bağdat'ta hazırlandığını göstermektedir (Resim 1).

Resim 1. Silsilenâme, Ketebe kaydl, TSMK H. 1591, y. $14 a$.

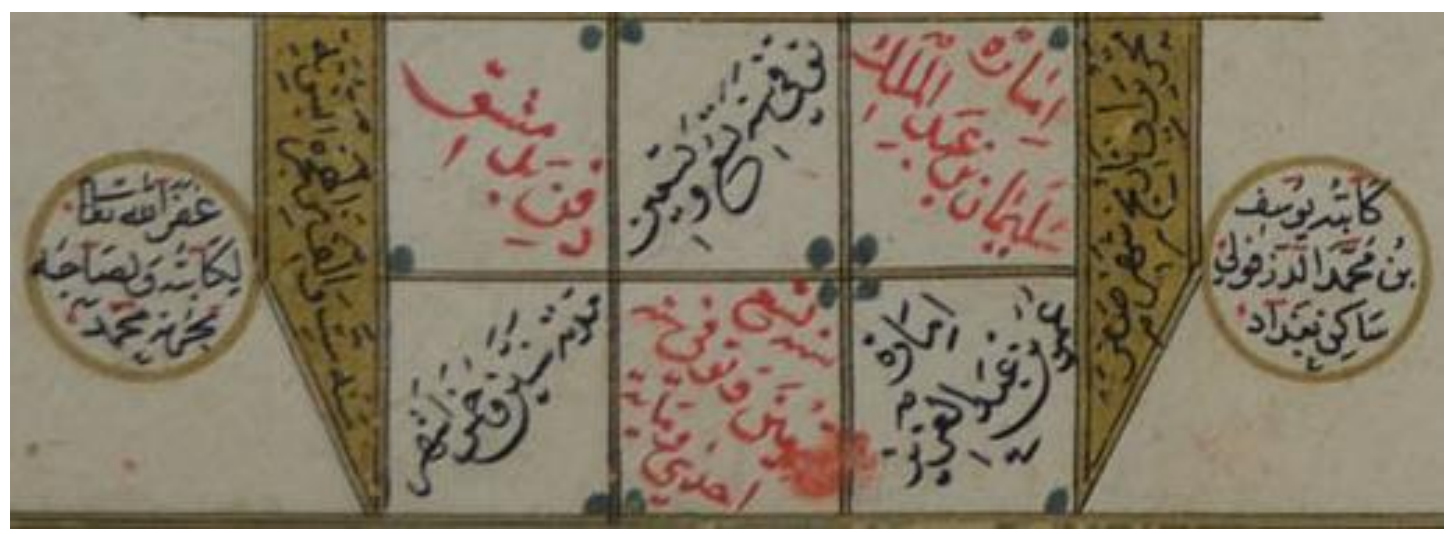

Kaynak: Ayğan, A. (2017). Osmanlılarda silsile geleneği ve resimli hanedan silsilenâmeleri (Tez No. 469387) [Doktora Tezi, Mimar Sinan Güzel Sanatlar Üniversitesi]. Yükseköğretim Kurulu Ulusal Tez Merkezi'nden edinilmiştir.

İkinci grupta yer alan TSMK A. 3110 ve TSMK H. 1624 numaralı eserlerin ketebe kaydı bulunmamaktadır. Fakat metinlerin birinci gruptakilerle birebir uyması ve minyatürlerin üslup ve ikonografisi bu eserlerin de Bağdat'ta üretilmiş olma ihtimalini güçlendirir.

Birinci gruptaki nüshalar üç bölümden oluşmaktadır. Birinci bölüm, Hz. Muhammed'in şeceresi, ikinci bölüm silsilenâmenin ana metni, üçüncü bölüm ise minyatürlü bölümdür. Şecere içermeyen İkinci grup nüshalar dünya tarihinin özet biçimde anlatıldığı silsilenâmelerin ana metin bölümü ile başlamaktadır. İki grup arasındaki önemli farklardan biri de yazı stilidir. Birinci grupta yer alan nüshalar nesih-sülüs yazısı ile ikinci gruptakiler ise talik yazı stili ile yazılmıştır.

Silsilenâmelerdeki minyatürlü madalyon sayıları da değişmektedir. TSMK H. 1591'de 95, TSMK A. 3110'da 90, TSMK CBL T.423'te 84, TSMK H. 1324'te 79, TSMK H. 1624'te ise 67 minyatürlü madalyon yer alır. Bağdat Silsilenâmelerindeki madalyonlar Sultan III. Mehmed ile sona erer. TSMK A. 3110 numaralı nüsha ise farklı dönemlerde yapılan ilavelerle II. Mustafa'ya kadar uzatılmıştır (Resim 2). İstisna olarak Dublin nüshasında Kanuni Sultan Süleyman Osmanlı dizisinin son hükümdarı olarak görünmektedir. Fakat eserde sonraki sayfaların eksik olduğu açıktır. Çünkü son hükümdarın kenar bilgilerinde ölüm tarihi yer almazken, bu nüshada Sultan Süleyman'ın ölüm tarihi verilmiştir.

Bağdat'ta hazırlanan resimli silsilenamelerden dördü Topkapı Saray Müzesi Kütüphanesi'nde H.1591, H.1324, H.1624, A.3110 numaralarıyla kayıtlıdır. Bu dört nüshayla benzerlik gösteren başka bir resimli örnek ise Dublin Chester Beatty Library'de T.423 numarasıyla kayıtlıdır. Söz konusu beş nüsha, sayfa düzeni, silsilede yer alan isimler, minyatürlerin üslup ve ikonografisi açısından benzerlik gösterse de yazmalar arasında birtakım farklılıklar mevcuttur. Bu sebeple söz konusu beş eseri iki grupta irdelemeyi uygun görmekteyiz. Aralarındaki farklılıklara geçmeden önce ortak noktaları üzerinden Silsilenâmelere ana hatlarıyla değinmeye çalışacağız. Silsilenâmeler genel olarak iki bölümden oluşur. Birinci bölüm metin bölümü, diğer bölüm ise şematik çizelgelerden oluşan madalyonlu bölümdür. Topkap1 Saray Müzesi Kütüphanesi'ndeki iki nüsha (TSMK H. 1324, TSMK H. 1591) ile Dublin Chester Beatty Library'de bulunan bir nüsha (CBL T. 423) ilave bir Hz. Muhammed şeceresi içermektedir. Girişte yer alan bu şecere, İbnü'l-Mibred lakaplı Yusuf b. Abdulhâdi'ye (ö. 909) ait olan "eş-Şeceretü'n-nebeviyye" olarak bilinen eserdir. Osmanlı sultanları için hazırlanan silsilelerin başına 
Hz. Muhammed'in soyunun ilave edilmesi bu eser türüne ilgiyi arttırmayla alakalı bir durum olarak değerlendirilebilir.

Resim 2. Silsilenâme, Sultan IV. Mehmed, Sultan II. Süleyman, Sultan II. Ahmed, Sultan II. Mustafa, TSMK A. 3110, y. 18b-19a.

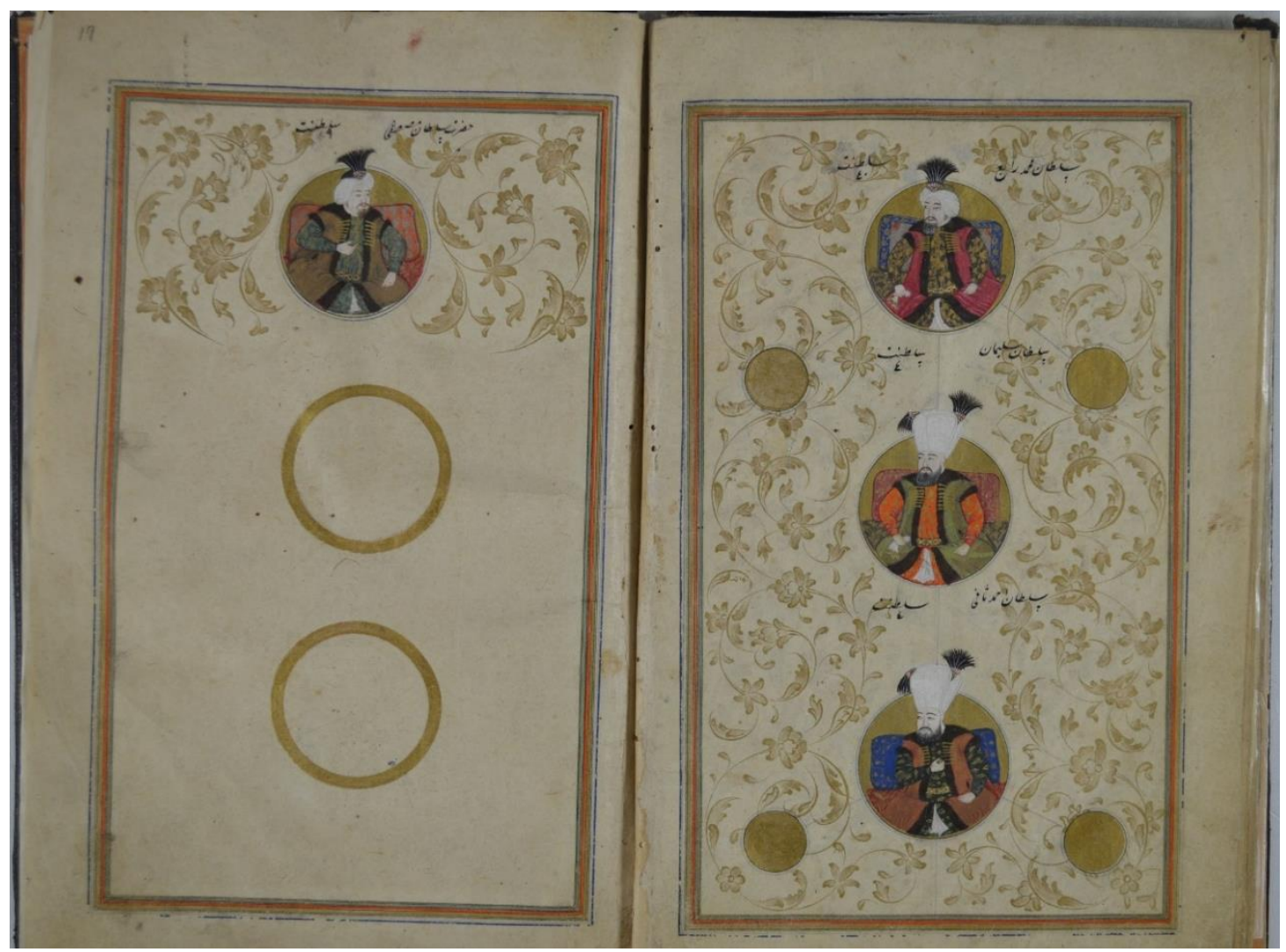

Kaynak: Ayğan, A. (2017).

Eserin müellifi Yusuf b. Abdulhâdi aslında bir şecere yazarı veya Ensâb konusunda eser üreten bir ilim adamı olmayıp, Hanbeli ekolüne mensup bir fâkih ve hadis bilginidir (Koca, 2000, s. 126). Eserin girişinde müellif bu şecereyi, bir arkadaşı aracılığı ile tanıdığını ve arkadaşının kendisinden eserdeki birtakım eksiklikleri düzeltmesini istediğini ifade etmiştir (Zübdetü târih, 1006a, s. 2a).

\section{Kurgu ve tasarım}

Şecere içeren üç nüsha (TSMK H. 1324, TSMK H. 1591, CBL T. 423) standart bir kurgu ve tasarıma sahiptir. Eserler çift sayfa müzehhep serlevha ile başlamaktadır (Resim 3). Karşılıklı tezhipli sayfalar simetrik biçimde tasarlanmıştır. Zeminlerde lacivert ve altın renklerinin kullanıldığı kompozisyonda kartuşların iç kısımları birbirini tekrar eden kıvrık dallarla süslenmiştir.

Bu iki sayfada Allah'a şükür, Peygambere salat ifadelerinden sonra müellif kendisini ve eserini tanıtır. İki sayfalık metinden sonra Hz. Muhammed'in ve dört büyük halifenin soyu başta olmak üzere, önemli sahâbilerin ve Hz. Muhammed'in akrabalarının soyu şema halinde sunulur. Sonraki sayfalarda ise Hz. Muhammed'in sahip olduğu hayvanlar ve kullandığ eşyalar hakkında bilgi verilir. Sonunda ise ilk vahyin gelişinden başlamak üzere Emevi halifesi Ömer b. Abdulaziz'in (717-720) halifeliğine kadar geçen süredeki bir takım önemli olaylar kronolojik sıraya uygun biçimde kutucuklar içerisinde verilmiştir (Zübdetü târih, 1006b, y. 13b-14a).

Silsilenâmelerin ana giriş bölümü ise haşiyeli bir unvan tezhibi ile başlamaktadır (Resim 3). İlk sayfada Farsça kelimelerin yoğun olarak kullanıldığı edebi bir dille Allah'a şükür ifadeleri, Adem'in yaratılış serüveni ve Hz. Muhammed'in seçkin bir kul olarak insanlar arasından son peygamber olarak gönderilmesi gibi konular yer alır. Bu ifadelerin ardından padişahın adı övgüyle belirtilir. Sonrasında 
ise dünya tarihi ile ilgili özet bilgilere yer verilir. Metinde Âdem peygamberden başlamak üzere $\mathrm{Hz}$. Muhammed'e kadar özellikle Kur'an'da kıssaları yer alan peygamberler ve aralarındaki zaman dilimi, Tevrat ve İncil dâhil olmak üzere çeşitli dini kaynaklardan rivayetler eşliğinde anlatılır. Peygamberlerden sonra dünyada hüküm sürmüş saltanatlar ve devletler "tabaka" ismiyle İslam öncesi ve sonras1 olarak önce ikiye; sonra kendi içinde İslam öncesi sultanlar dört tabakaya, İslam sonras1 dönem ise on tabakaya ayrılmış ve her tabakada kaç hükümdarın yer aldığı belirtilmiştir (Zübdetü târih, 1006a, y. 15b-19a). Bu metin bölümü madalyonlu bölümün özet bir girişidir.

Resim 3. Silsilenâme, Serlevha, TSMK H. 1324, y. 1b-2a.

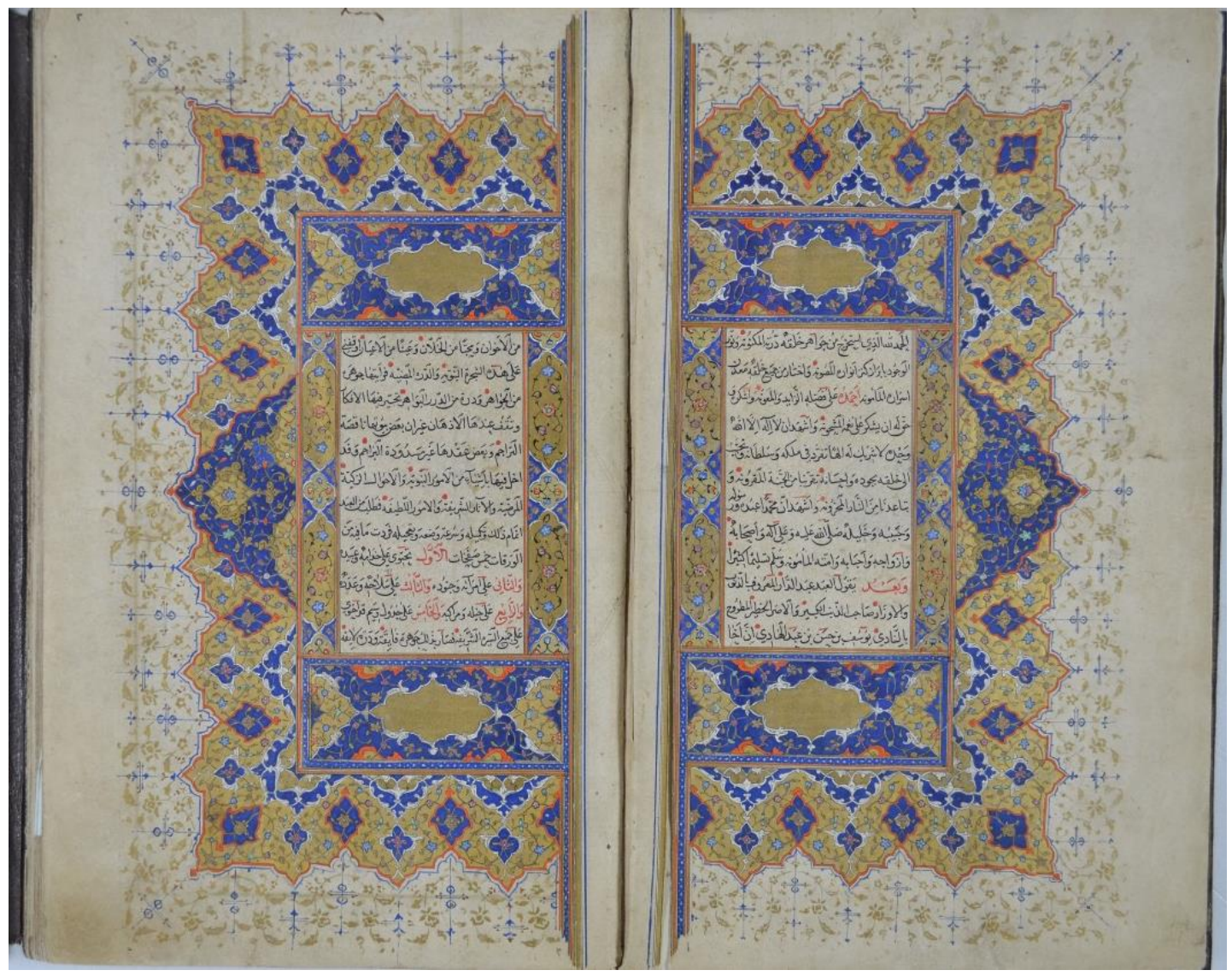

Kaynak: Ayğan, A. (2017).

Üçüncü bölüm ise minyatürler içeren şematik bölümdür. Önceki bölümde genel bir sınıflandırma içerisinde tanıtılan hanedanlar detaylı olarak ele alınır. Kimi hükümdarların madalyonlar içerisine portreleri çizilmiş̧en, kimilerinin ise sadece ismi yazılmıştır. Hükümdarlar arasındaki soy ilişkisi madalyonlar arasındaki oklarla şematik biçimde ortaya konmuştur.

Kitap olarak tasarlanmış bu eserlerin sayfa tasarımına bakıldığında aslında rulo mantığının olduğunu görmekteyiz. Âdem peygamberden başlayan madalyonlar oklarla birbirine bağlanarak her sayfa bir önceki sayfanın devamı olarak kesintisiz biçimde devam eder. Her sayfanın üst kısmında önceki sayfada nesil kaç koldan devam ettiyse o sayıda madalyon yer alır. Böylelikle eserde hem önceki sayfa ile bütünlük sağlanmış hem de eser kitap formatına uygun hale getirilmiştir. Hanedanlar kısmında madalyonların arasında kalan yerlere ismi geçen sultanlara ait bilgiler yazılmıştır. Yazılar ve madalyonlar her sayfaya özenle yerleştirilmiş, böylece kitap sanatları açısından nadide bir sayfa tasarımı ortaya çıkmıştır.

İslam sonrası dönem Abbasi tabakası (Tabakâ-yı Abbâsiyan) ile başlar. İslam dönemindeki her hanedanın başında o hanedanın kuruluşu ve kurucusuyla ilgili bir metin yer alır. Bu metinler şematik tasarıma uygun olarak bir kutucuk içerisine yazılmıştır. Bunun dışında madalyonlar arasında kenar yazıları kullanılmamış, sadece minyatürlü olmayan madalyonlarda sultanın ismi yazılmıştır. Osmanlı 
tabakasına geçildiğinde ise karşılıklı iki sayfayı dolduracak şekilde metin kısmı uzun tutulmuş ve madalyonların çevresinde dairesel biçimde kenar yazıları yer almıştır (Zübdetü târih, 1006a, y. 27b28a).

Erken dönem sultanlarıyla ilgili kenar yazılarının bir bölümü tarihi birtakım verilere dayanmakta bir bölümü ise efsanevi anlatımlar içermektedir. Metinlerde yer alan bu efsanevi hikâyelerin birçoğu Firdevsi'nin (ö. 1020) meşhur eseri olan Şehnâme'de geçmektedir. Ayrıca peygamber madalyonlarının kenarlarında verilen bilgilerin de Taberi tarihi ile uyuştuğu görülmektedir. Osmanlı soyu Nuh oğlu Yâfes'ten başlatılır ve madalyon kenarında Türklerin Nuh oğlu Yâfes soyundan geldiği belirtilmiştir (Taberi, 1991, s. 265; Zübdetü târih, 1006a, s. 22a). Cemşid ve Dahhâk gibi efsanevi karakterler hakkında verilen bilgiler de Şahnâme'deki anlatımlarla örtüşmektedir (Firdevsi, 1994, ss. 81, 104; Zübdetü târih, 1006a, s. 21a).

\section{Minyatürlerde üslup ve ikonografya}

Silsilenamelerin şematik bölümünün başlangıç kısımlarında Âdem ile başlayan peygamberler dizisi ile kadim İran hükümdarlarının dizileri birlikte ilerler. Bu dizilerdeki metinler sonraki bölümlere nispeten daha çok yer kaplamaktadır. Bu bölümün minyatürleri dini ve efsanevi anlatımları pekiştiren bir özellik gösterir. Metinde anlatılan akıcı dil ve canlı üslup tasvirlere de yansır. Bu minyatürlerde karşımıza çıkan, karikatürize formlar ve başları vücutlarına oranla büyük tasvir edilen iri sarıklı figürler Bağdat okulunun karakteristik özelliklerini yansıtmaktadır (Mahir, 2005, s. 67). Bununla birlikte özellikle Osmanlı sultanlarının yer aldığı madalyonlardaki portreler Nakkaş Osman'ın geliştirdiği modellere dayanmaktadır (Bağc1, 2000, s. 199).

Minyatür sayıları nüshalara göre değişmektedir. Eserlerde daha çok tarihte önemli yeri olan karakterlerin betimlendiğini söyleyebiliriz. Madalyonlar içerisinde çoğunlukla bir karakterin minyatürü yer alsa da bazı madalyonlarda iki karakterin birlikte betimlendiği görülür. TSMK H. 1624 numaralı nüshada Âdem ve Cebrail madalyonu, Hâbil ve Kâbil madalyonu buna örnek olarak gösterilebilir. Bunlardan Kâbil'in kardeşi Hâbili öldürme sahnesi silsilename nüshaları arasında dikkat çeker. Altın zeminli madalyonda Hâbil, bir eli başının altına almış, gözleri kapalı uyur vaziyettedir. Kâbil ise diz üstü oturuş pozisyonunda büyükçe bir taş tutmaktadır. Taşın bir hayvan başı görünümlü olması olayın kötülüğüne bir vurgu olarak düşünülebilir. (Resim 4).

Resim 4. Silsilename, Kâbil'in Hâbil'i öldürmesi, TSMK H. 1624, y. 5b-y.6a.

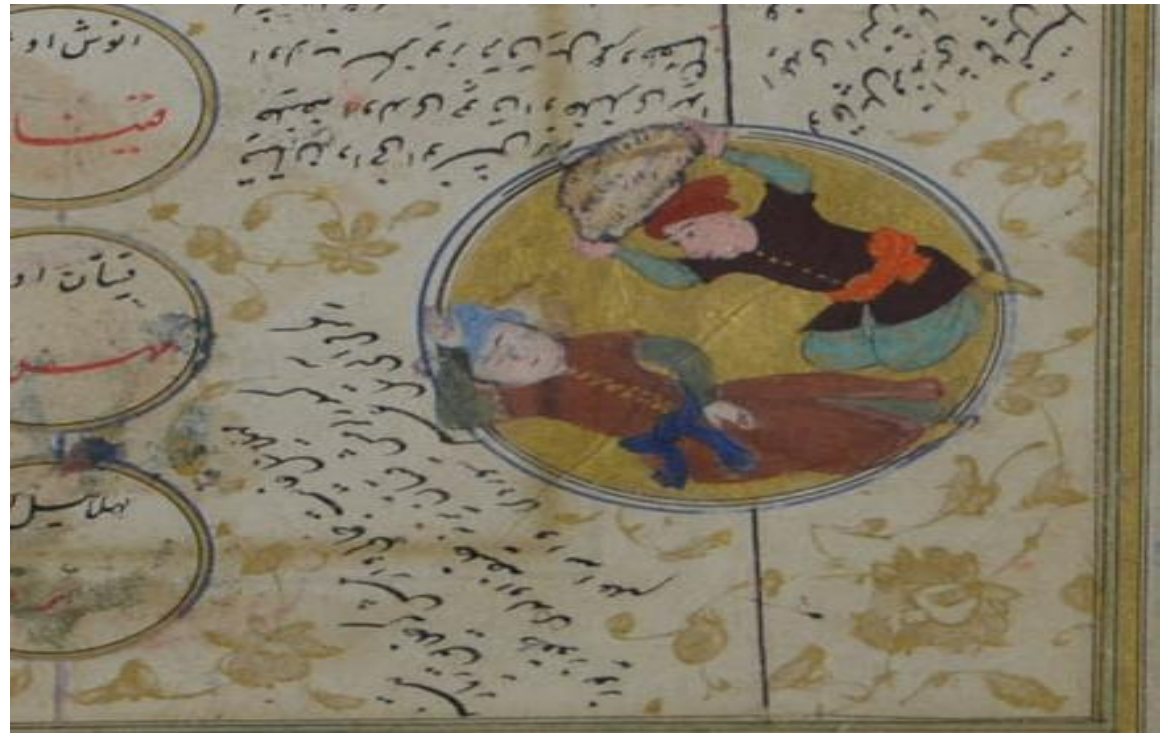

Kaynak: Ayğan, A. (2017).

Eserlerde yer alan minyatürler, önemli ikonografik ayrıntılar içermektedir. Madalyonlar içerisinde betimlenmiş bu minyatürlerin bir bölümü portre niteliği taşımaktadır. Fakat erken dönem peygamberler ile kadim hükümdarlar, içerdiği ikonografik unsurlarla bir karakterin imgesinden öteye geçerek bir olayı 
anlatır hale dönüşmüştür. Örneğin Salih peygamber madalyonunda, ellerini göğe kaldıran Salih peygamberin yanında bir deve betimlenmiş, Salih peygamberin kendisinden mucize isteyen topluluk karşısında Allah'a dua etmesi ve mucizenin gerçekleşmesi canlandırılmıştır (Resim 5).

Resim 5. Silsilenâme, Sâlih Peygamber ve devesi, Dublin CBL T. 423, y. $18 \mathrm{~b}$.

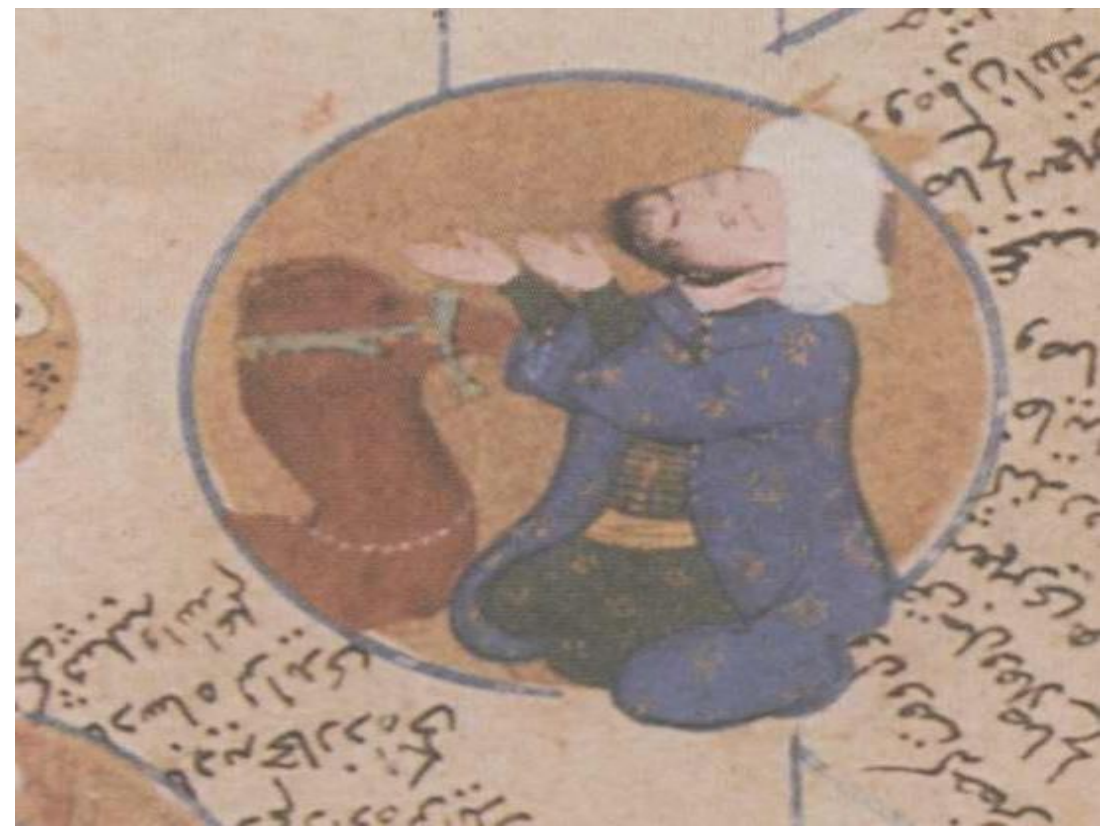

Kaynak: Bayram, S. (1994).

Eserlerde dini karakterler ile hükümdarlar farklı ikonografik öğelerle birbirinden ayrılır. Peygamberler sarıklı ve sakallı olarak betimlenmiş, başlarından yukarı doğru uzanan haleler ile kutsal kimliklerine vurgu yapılmıştır. Ayrıca ellerinde veya bir rahle üzerinde genellikle bir kitap bulunmaktadır. Bunların yanı sıra kimi peygamberlerin madalyonlarında Kur'an'da geçen kıssalarla örtüşen detaylara yer verilmiştir. Saray mensuplarının ise en belirgin ikonografik özelliği başlıklarıdır. Dilimli kral taçları, yırtıcı hayvan başı gibi başlıklar, bazı karakterlerin ellerinde tutukları kadeh ve çiçekler Orta-Asya'ya dayanan Türk resim sanatındaki saray mensuplarının ikonografik izlerini gösterir niteliktedir (Esin, 1970, s. 226).

Silsilenâmelerde "Altın çizgi” olarak vurgulanan Nuh oğlu Yâfes'ten Osmanlı Sultanlarına uzanan soy dizisinde, Osmanlı öncesi Türk hükümdarları ile Osmanlı dönemi hükümdarları arasında da belirgin farklılıklar vardır. Osmanlı öncesi hükümdarlar dilimli kral tacı ve kürklü kaftan sıklıkla tercih edilmişken Osmanlı dizisinde sultanlar sarıklı olarak gösterilmiştir (Resim 6). Bu dizideki portreler daha önce de ifade edildiği gibi Nakkaş Osman'ın kalıplarının küçültülmüş modelleridir. Bağdatlı sanatçıların Osmanlı padişah portrelerindeki standartlaşmış imgelere bağlı kaldıkları görülmektedir. II. Bayezid'in koyu tenli ve yaşlıca hali, I. Selim'in (Yavuz) sakalsız, gür bıyıklı imajı, II. Selim'in kızıla çalan sakalı gibi Osmanlı sarayındaki kalıplaşmış ifade biçimleri Bağdat'taki atölyelerde tekrar etmiştir. Osmanlı dizisi eserlerin hazırlandığ 1 tarihte hayatta olan III. Mehmed ile son bulmaktadır. Önceki sultanların kenar bilgisinde rahmetullâhi 'aleyh (Allah'ın rahmeti üzerine olsun) yazarken, III. Mehmed

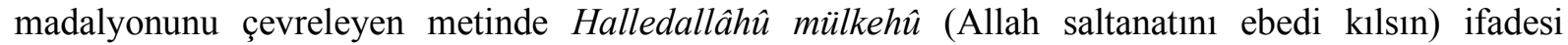
yazılmıştır (Resim 7). Bu ifadeler sultanın halen tahtta olduğunu göstermektedir. III. Mehmed yukarı doğru uzanan sorguçlu görece gösterişli bir başlık ve kolsuz bir kaftanla gösterilmiştir. Bağdaş kurma oturuş pozisyonuyla betimlenen sultanın siyah gür sakalı onu dizideki portrelerden ayıran temel özelliğidir. 
Resim 6. Silsilenâme, Gazneli Mahmud, Dublin CBL T. 423, y. $23 a$.

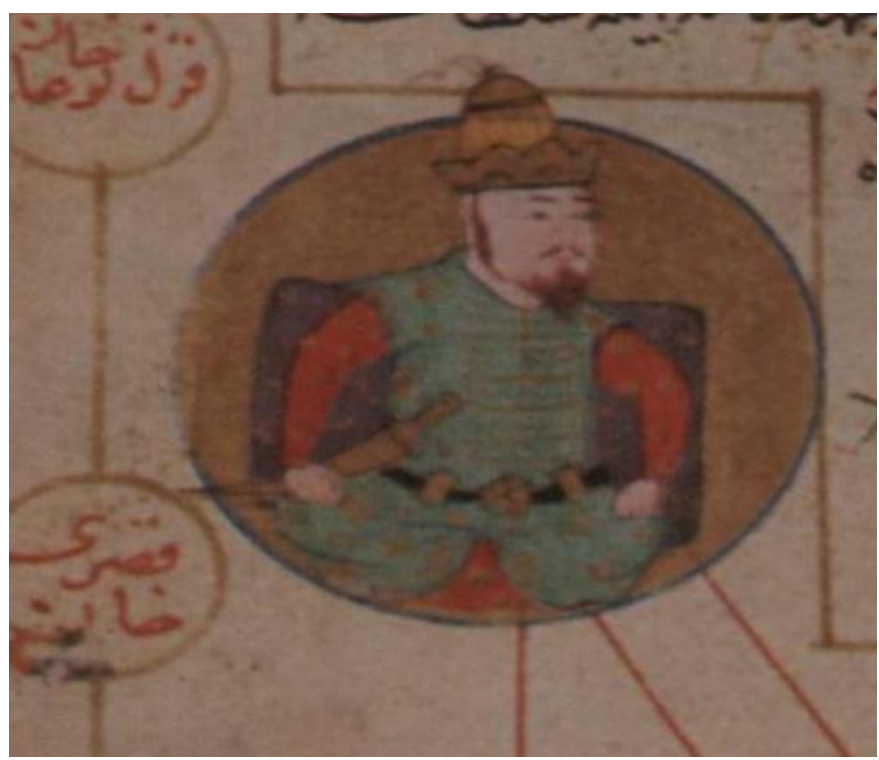

Kaynak: Bayram, S. (1994).

Resim 7. Silsilename, III. Mehmed, TSMK H. 1324, y. 30a

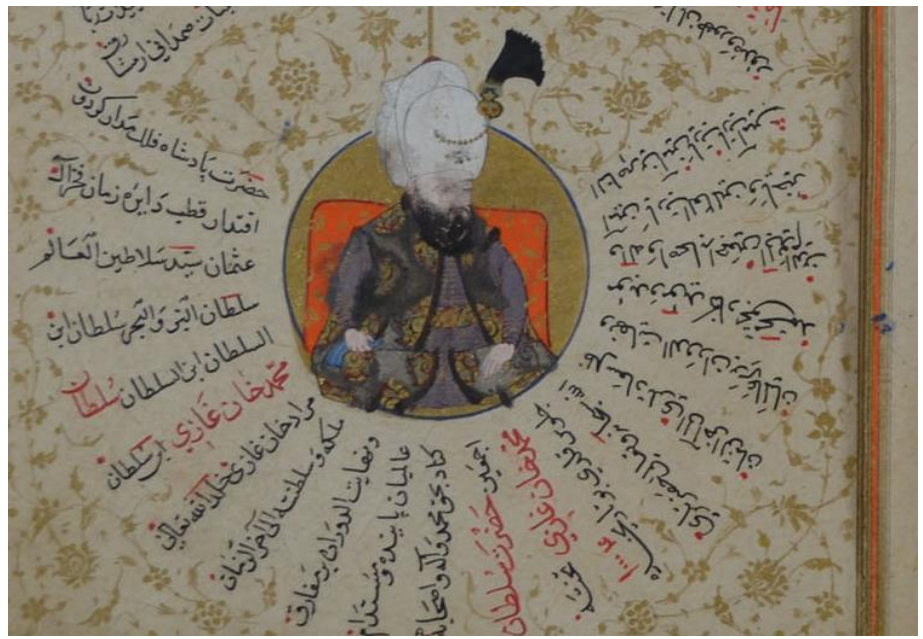

Kaynak: Ayğan, A. (2017).

\section{Sonuç}

Osmanlı devletinin Bağdat'ta hâkimiyet kurma mücadelesi 16. yüzyıl boyunca devam etmiştir. Safevi ile Osmanlı arasında güç savaşı bu yüzyılda Osmanlı lehine sonuçlanmıştır. Osmanlılar kazanmış olduğu siyasi zaferi pekiştirmek amacıyla eyalette kültür ve sanat alanında faaliyetler yürütmüşlerdir. Sokullu ailesinin dirayetli üyesi Hasan Paşa eyalete vali olarak atanmış ve Osmanlı kimliğinin bölgeye hâkim olmasında çaba göstermiştir.

Tam olarak hangi sebeplerle ve kimin hâmiliğinde başladığı tespit edilemeyen resimli Silsilenâmeler Bağdat'ta 16. yüzyıl sonlarında başlayan resimli el yazması üretimlerinin önemli bir parçasıdır. Bağdat'ta benzer dönemlerde hazırlanan eserlerin minyatürlerindeki canlı ve hareketli üsluba silsilenâmelerde kadim dönem hükümdarlar ve peygamber madalyonlarında rastlamaktayız. Osmanlı dizisindeyse saraydaki standart kalıplara sıkı sıkıya bağlı kalındığını görmekteyiz.

Osmanlıların en önemli kültür merkezlerinden biri olan Bağdat'ta hazırlanan ve birbirinin kopyası olduğu anlaşılan silsilenâmeler Osmanlı kültür ve sanatı açısından değer taşıyan el yazması 
eserlerdendir. Osmanlı hanedanının soyunu müstakil olarak ele alan yegâne bir türdür. 15. yüzyıldan itibaren sürekli gelişim gösteren bu tür 16. yüzyıl sonlarında standart bir görünüme kavuşmuştur. Eserlerde minyatürler, çizelgeler ve bunlar arasında kalan yerlerdeki metin kuşakları sayfa içerisinde ahenk içerisinde sunulmuştur. Madalyonlar içerisinde betimlenen minyatürler, Osmanlı portre sanatının önemli gelişim aşamalarından biri olarak değerlendirilmektedir. Bu portre minyatürler sonraki dönem sanatçılara ilham kaynă̆ı olmuştur. 17. yüzyılda Musavvir Hüseyin (ö. 1691); 18. yüzyıldaysa öğrencisi olduğu varsayılan Levni (ö. 1732) ile Osmanlı portre sanatı ileri noktaya ulaşmıştır.

Ayrıca İlk İnsan Hz. Âdem'den başlanarak, Hz. Muhammed'e kadar peygamberlerin soyunun anlatıldığı ve Osmanlı sultanları ile sonlandırılan bu eser, Osmanlıların medeniyet algısının ipuçlarını da bizlere sunmaktadır. Tarihsel köklerine inmek suretiyle saltanatı dini kimlikle bütünleştiren bu eserler, yayıldığı tüm coğrafyalarda Osmanlı imparatorluğunun meşrulaştırılmasında önemli rol oynamıştır. 
EKLER

Tablo 1.

\begin{tabular}{|c|c|c|c|c|c|c|c|}
\hline & 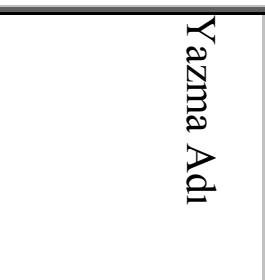 & 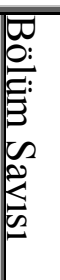 & 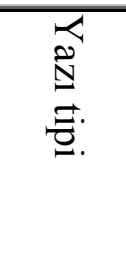 & $\overrightarrow{\text { ज्: }}$ & 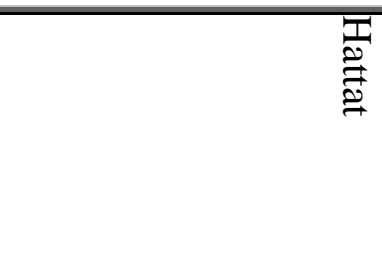 & 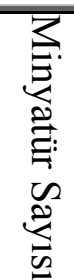 & 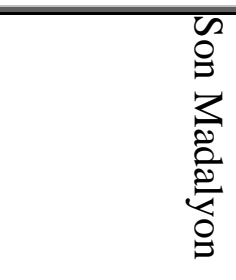 \\
\hline \multirow{3}{*}{ - } & $\begin{array}{l}\text { TSMK H. } \\
1591\end{array}$ & 3 & $\begin{array}{l}\text { Nesih } \\
- \\
\text { Sülüs }\end{array}$ & 1006 & $\begin{array}{l}\text { Yusuf b. Muhammed } \\
\text { Dizfûlî }\end{array}$ & 95 & III. Mehmed \\
\hline & $\begin{array}{l}\text { TSMK H. } \\
1324\end{array}$ & 3 & $\begin{array}{l}\text { Nesih } \\
\text { - } \\
\text { Sülüs }\end{array}$ & 1006 & $\begin{array}{l}\text { Yusuf b. Muhammed } \\
\text { Dizfûlî }\end{array}$ & 79 & III. Mehmed \\
\hline & DCBL T. 423 & 3 & $\begin{array}{l}\text { Nesih } \\
- \\
\text { Sülüs }\end{array}$ & 1006 & Ebû Tâlip el-İsfehânî & 84 & I. Süleyman \\
\hline \multirow[b]{2}{*}{$\stackrel{N}{i=0}$} & $\begin{array}{l}\text { TSMK H. } \\
1624\end{array}$ & 2 & Talik & t.y & Ketebe kaydı yok & 67 & III. Mehmed \\
\hline & $\begin{array}{l}\text { TSMK A. } \\
3110\end{array}$ & 2 & Talik & t.y & Ketebe kaydı yok & 90 & II. Mustafa \\
\hline
\end{tabular}




\section{Notlar:}

1. Sokollu Mehmet Paşa 16. yüzyıl Osmanlı yönetiminde uzun süre etkin rol üstlenmiş bir devlet adamıdır. Sadrazamlığı döneminde kimi resimli el yazmalarının hazırlanmasında da öncülük etmiştir. Onun Osmanlı idaresindeki etkisini yansıtan eserlerin başında Nüzhet-i esrârü'l-ahyâr der-ahbâr-1 sefer-i Sigetvar gelmektedir. Yüzyılın sonlarına doğru oğlu Hasan Paşa da Osmanlı bürokrasisinde kariyer sahibi bir figür olarak görünür. 1598 yılında Bağdat valiliğine atanan Sokulluzâde Hasan Paşa, görev yaptığı sırada aralarında silsilenamelerinde bulunduğu resimli tarih eserlerinin Bağdat' taki atölyelerde hazırlanmasını sağlamıştır. Konuyla ilgili bkz. (Değirmenci, 2017, s. 176; Taner, 2019, s. 62-65)

2. İslam-Osmanlı kültüründe Silsilenâme geleneği, sınıflandırılması ve günümüze ulaşan örnekler için bakınız. (Ayğan, 2017, s. 11-78), Günümüze ulaşan resimli Bağdat nüshaları için bkz. (Taner, 2016, s. 218; Ayğan, 2017, s. 3) 


\section{KAYNAKÇA}

Ayğan, A. (2017). Osmanlılarda silsile geleneği ve resimli hanedan silsilenâmeleri (Tez No. 469387) [Doktora Tezi, Mimar Sinan Güzel Sanatlar Üniversitesi]. Yükseköğretim Kurulu Ulusal Tez Merkezi'nden edinilmiştir.

Bağc1, S. (2000). Adem'den III. Mehmed'e: Silsilenâme. İçinde, Padişahın portresi: Tesavir-i Al-i Osman (Çev. Jale Alguadiş \& Serpil Bağcı), Türkiye İş Bankası Yayınları (188-201).

Bağcı, S., Çağman, F., Renda, G., \& Tanındı, Z. (2006). Osmanlı Resim Sanatı. Kültür ve Turizm Bakanlığı.

Bayram, S. (1994). Silsile-nameler ve İrlanda-Dublin, Chester Beatty Library'de Bulunan 1598 Tarihli Zübdetü't-Tevarih, Vakıflar Dergisi, 24, 51-116.

Çağman, F. (1979). XVI. yüzyıl sonlarında mevlevi dergahlarında gelişen bir minyatür okulu. I. Milletlerarası Türkoloji Kongresi, (ss. 651-677), İstanbul.

Değirmenci, T. (2017). Bir Osmanlı paşasının padişahlık rüyası: Sokulluzâde Hasan Paşa ve resimli dünya tarihi. Osmanl Araştırmaları, 49(49), 171-202.

Esin, E. (1970). “And”, the Cup Rites in Inner-Asian and Turkish Art. D.ed. 1970.

Firdevsi, el-Firdevsî et-Tusî. (1994). Şahnâme (N. Lugal, Çev. C. 1). Ankara: Milli Eğitim Bakanlığı.

Koca, F. (2000). İbnü'l-Mibred”. TDVIA (126-128)

Mahir, B. (2005). Osmanlı minyatür sanatı. Kabalcı Yayınevi.

Pakalın, M. Z. (1983). Osmanlı tarih deyimleri ve terimleri sözlüğü: C. 3. Milli Eğitim.

Taberi, Muhammed b. Cerir. (1991). Milletler ve hükümdarlar tarihi. (TDV İslâm Araştırmaları Merkezi; C. 1). Milli Eğitim Bakanlığı.

Taner, M. (2016). "Caught in a whirlwind:" Painting in Baghdad in the late sixteenth-early seventeenth Centuries, Harvard University, History of Art and Architecture.

Tosun, N. (2009). Silsile. TDVIA, (206-207).

Zübdetü târih (H. 1324). (1006a). TSMK.

Zübdetü târih (T. 423). (1006b). CBL. 